\title{
EFFECT OF CRUSHED SAND AND BACILLUS SUBTILIS ON THE CANTABRO LOSS OF BACTERIAL CONCRETE
}

\author{
C. Venkata Siva Rama Prasad ${ }^{1 *}$, T.V.S. Vara Lakshmi ${ }^{1}$ \\ ${ }^{1}$ Department of Civil Engineering, University College of Engineering \& Technology, Acharya \\ Nagarjuna University, Nagarjuna Nagar, Guntur Dist., Andhra Pradesh., India-522510
}

(Received: August 2018 / Revised: November 2018 / Accepted: April 2019)

\begin{abstract}
Bacterial concrete has emerged as a remedial measure for healing cracks in structures such as bridges, RCC buildings, RCC pipes, canal linings and pavements. Crack formation is an extremely common occurrence in concrete structures, and allows water and different chemicals to enter the concrete through cracks, diminishing its strength. In addition, it has consequences on the reinforcement once it comes into contact with water, $\mathrm{CO}_{2}$ and other chemicals. The repair of cracks within concrete requires regular maintenance and special kinds of treatment, which can be very expensive. In bacterial concrete, particular types of microorganism can be extremely useful for refurbishing cracks in existing concrete structures. In this research, an experimental investigation was made to prevent cracks in concrete using Bacillus subtilis bacteria and calcium lactate. Bacillus subtilis bacteria with calcite lactate were used at varying percentages of 5\%, $10 \%$ and $15 \%$ cement weight for M40 grade concrete. The fine aggregate used in all the mixes was crushed rock sand. A Cantabro loss test was conducted for all the mixes after 3, 7, 14 and 28 days of curing. An empirical relation between flexural and compressive strength is proposed in the form of $f_{t}=0.66 \sqrt{f_{c k}}$ for river sand mixes and $f_{t}=0.89 f_{c k}^{0.46}$ for crushed rock sand. An empirical relation is also proposed between Cantabro loss and flexural strength for bacterial concrete.
\end{abstract}

Keywords: Bacillus subtilis; Bacterial concrete; Cantabro loss; Compressive strength; Flexural strength; Split tensile strength

\section{INTRODUCTION}

In any building construction, cement concrete is a primary substance in the modern era of infrastructural projects across the globe. Like this material is lying face down to fracture in arrears towards in elastic and less resistant to straining demands the practice of rebar in it. Since it bonds with steel bars, concrete becomes more effective in resisting tension than without any reinforcement, and the tensile strength of concrete is relatively lower than compressive strength. Any cracks that have formed expose the reinforcement and thus affect its structural integrity, leading to corrosion. However, it does crack and endure genuine wear and tear throughout the years of its predictable term of service (Wang et al., 2012) but is not versatile and cannot handle high levels of strain. Ordinary concrete can tolerate from near zero to $1 \%$ strain before giving out. Concrete that is able to heal on its own normally seeks to repair these flaws, thus increasing the service lifetime of any given concrete structure. There exists a material which is a type of

${ }^{*}$ Corresponding author's email: cvsrprasad90@gmail.com, Tel. +91-8008707104

Permalink/DOI: https://doi.org/10.14716/ijtech.v10i4.2299 
Self-healing concrete in growth which will solve several of the issues usually related with ordinary concrete (Ramadhansyah et al., 2011). Self-healing concrete consists of a mixture of microorganisms (Bacillus subtilis) fused into the concrete, and calcium lactate and nutrient broth food to support these microorganisms once they become active (Li \& Herbert, 2012). The microorganisms, feeding on the food supply provided, heal the cracks. This paper will make an in-depth case for the method that extent part behind microorganism that helps to heal the concrete, and describes the various parts that extent part enclosed within the process and the way they work severally and put together. The paper deals with sensible applications of self-healing concrete, as well as its real-world integration in structures. The abrasion resistance, i.e. surface abrasion loss and cantabro loss at various ages of concrete from 3 days to 90 days, is influenced by the flyash content and presence of M-Sand (Rao et al., 2016). To measure the abrasion resistance on pervious concrete, a new method is proposed in combination with other three methods (the loaded wheel test, surface abrasion test, and Cantabro test). They concluded that the Cantabro test shows promising results (Dong et al., 2010).

\subsection{The Biological Self-healing Process}

It is vital to hustle what forms of bacteria can live in concrete, however they effort to rise the robustness of structures, what the chemical agents are with the purpose of causes the biochemical process within the microorganism, what takes place in the precise forms of specialized microorganism once unprotected to the substance, and the mode they work along to not solely seal cracks before they form, but also strengthen the overall structure. Once the bacteria are uncovered to the atmosphere and for that reason become "food," the microorganisms stand an action that sources them to stabilize and wrath, filling in the crack that has formed. This method extends the robustness of the structure, additionally fixing any cracks that have occurred. The method of healing a crack takes around 28 days (Jonkers et al., 2010).

Concrete structures are presently designed in keeping with set standards that enable cracks to form up to $2 \mathrm{~mm}$ wide. Such small cracks are usually thought to be tolerable, as they do not directly weaken the structure. Moreover, small cracks generally patch themselves up, as numerous varieties of concrete display an explicit crack-healing capability. Analysis has shown that this 'autonomous' healing capability is essentially allied with the level of non-responded cement particles' ability in the concrete. In crack development, water acts in response to these elements, leading to the closure of small cracks. However, owing to the unpredictability of the self-directed crack remediation of concrete buildings, water run as a results of negligible crack creation in underpass and underground structures will occur. $0.2 \mathrm{~mm}$ (Zwaag, 2008; Reddy et al., 2012) wide-ranging cracks were observed to self-heal in conventional samples, while all the cracks were healed in the samples that contain bacteria. The fundamental idea behind our specific version of this technique is the utilization of sure categories of bacteria (in this case Bacillus subtilis) and approach of operate to closure tiny cracks within the concrete earlier they develop into bigger and further durable to manage cracks and fissures. This bio- calcification method involves many steps to complete the tasks (Jonkers \& Schlangen, 2007; Joseph et al., 2007).

Trendy techniques such as X-ray diffraction tests and scanning electron microscopy (SEM) analysis are employed to quantify the study of the stages of spar deposition (Kessler et al., 2003).

\subsection{How Do Bacteria Remediate Cracks?}

Once the mixing of concrete and bacteria is complete, the bacteria undergo inactive state. When they are exposed to the environment (air), all their functions are stimulated. When cracks form in concrete, the bacteria start to bring on calcite minerals to the crack (Ramakrishnan et al., 2001). At the point when the microorganisms interact with water and calcium lactate, the bacteria spores start germinating and the bacteria start feeding calcium lactate. This kind of pore is available in concrete up to two hundred years (Jonkers, 2011). Limestone heals cracks which have formed in 
concrete. By consuming the oxygen, the corrosion of steel decreases and the stability of reinforced concrete structures increases. The procedure of preparing synthetic calcium carbonate response from fractured calcium hydroxide can be identified properly (Schlangen et al., 2010).

$$
\begin{aligned}
\mathrm{CO}_{2}+\mathrm{Ca}(\mathrm{OH})_{2} & \rightarrow \mathrm{CaCO}_{3}+\mathrm{H}_{2} \mathrm{O} \\
\mathrm{CaC}_{6} \mathrm{H}_{10} \mathrm{O}_{6}+6 \mathrm{O}_{2} & \rightarrow \mathrm{CaCO}_{3}+5 \mathrm{CO}_{2}+5 \mathrm{H}_{2} \mathrm{O}
\end{aligned}
$$

\section{MATERIALS AND TESTING METHODS}

\subsection{Cement}

53 grade OPC was used in this experimental work. The OPC was tested as per IS 4031-1996, with its physical properties shown in Table 1.

\begin{tabular}{|c|c|c|c|}
\hline S. No. & Test Property & Result & Requirements as per IS $12269-1987$ \\
\hline \multirow[t]{3}{*}{1} & Fineness & & \\
\hline & (a) Sieve test & $2 \%$ & Not more than $10 \%$ \\
\hline & (b) Blaine & $285 \mathrm{~m}^{2} / \mathrm{kg}$ & $\operatorname{Min} 225 \mathrm{~m}^{2} / \mathrm{kg}$ \\
\hline 2 & Normal consistency & $31.0 \%$ & - \\
\hline 3 & Specific gravity & 3.01 & - \\
\hline 4 & Initial setting time & 95 minutes & Greater than 30 minutes \\
\hline 5 & Final setting time & 284 minutes & Less than 600 minutes \\
\hline \multirow[t]{4}{*}{6} & Compressive strength & & \\
\hline & (a) 3 days & $28 \mathrm{~N} / \mathrm{mm}^{2}$ & $27 \mathrm{~N} / \mathrm{mm}^{2}(\mathrm{Min})$ \\
\hline & (b) 7 days & $41 \mathrm{~N} / \mathrm{mm}^{2}$ & $37 \mathrm{~N} / \mathrm{mm}^{2}(\mathrm{Min})$ \\
\hline & (c) 28 days & $56 \mathrm{~N} / \mathrm{mm}^{2}$ & $53 \mathrm{~N} / \mathrm{mm}^{2}(\mathrm{Min})$ \\
\hline 7 & Soundness (Le-Chatlier Exp.) & $2 \mathrm{~mm}$ & Not more than $10 \mathrm{~mm}$ \\
\hline
\end{tabular}

Table 1 Physical properties of Portland cement (53 grade)

\subsection{Fine Aggregate}

Locally available river sand and crushed rock sand were used as fine aggregates. For the fine aggregate, the distribution of particle size is shown in Figure 1. The specific gravity of the river sand and crushed rock sand was 2.68 and 2.77 , respectively.

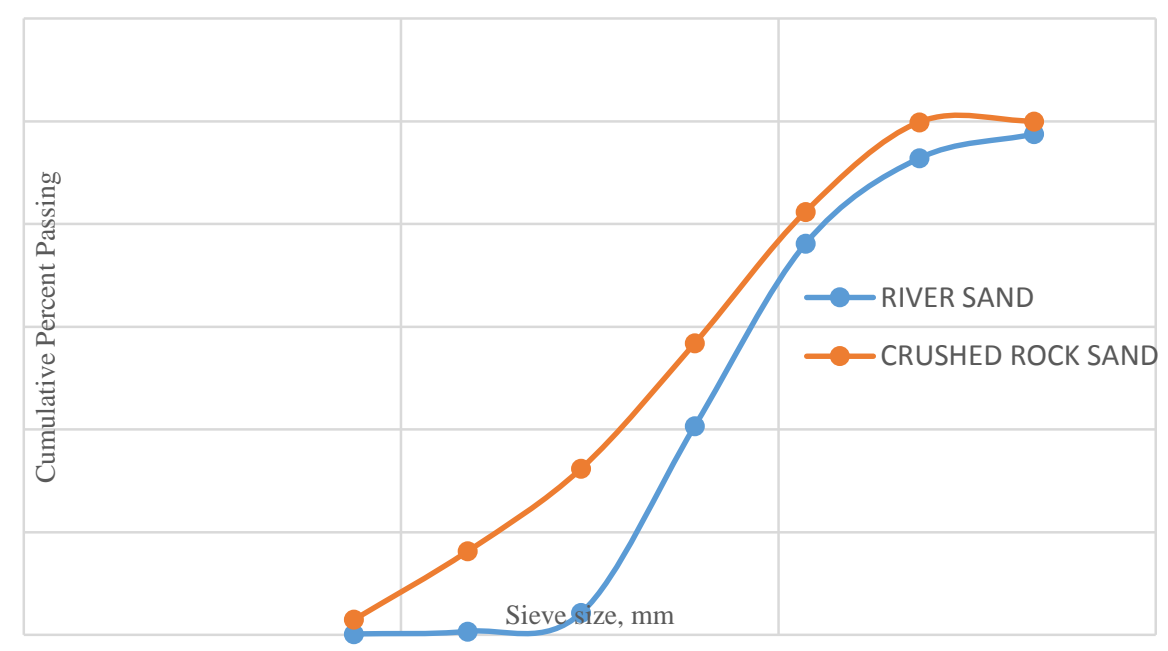

Figure 1 Particle size distribution curve of fine aggregate 


\subsection{Coarse Aggregate}

Crushed granite broken stone of $20 \mathrm{~mm}$ nominal size was used as coarse aggregate. The particle size distribution curves of the coarse aggregates are shown in Figure 2, with the specific gravity of the coarse aggregate being 2.71 .

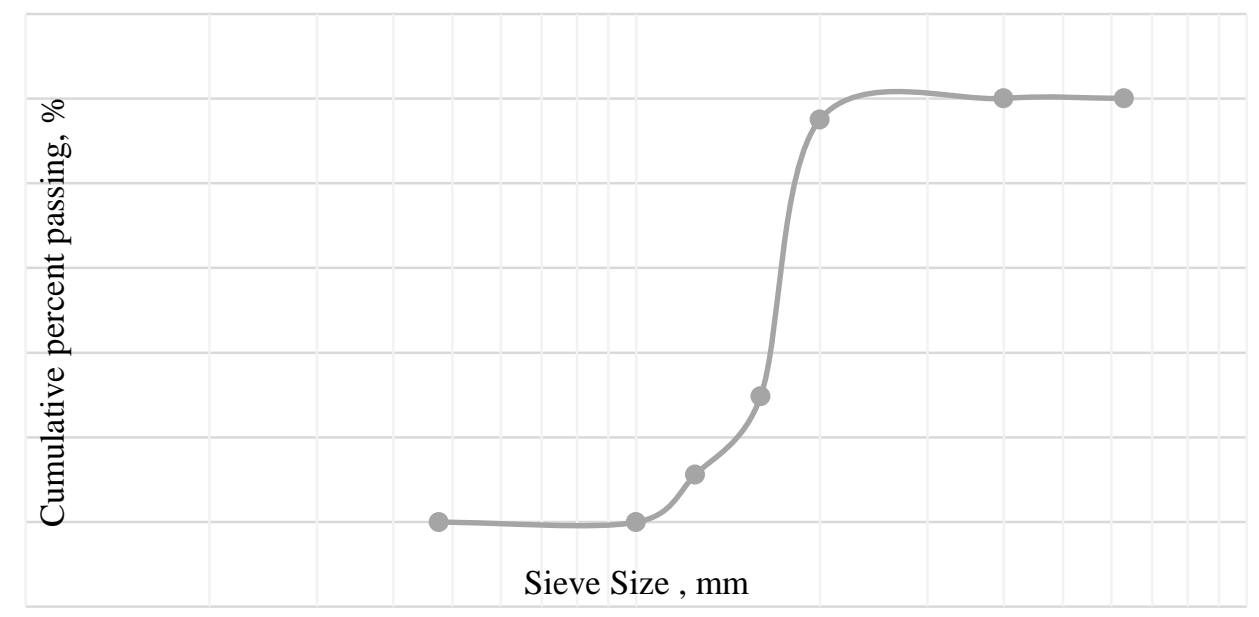

Figure 2 Particle size distribution curve of coarse aggregate

\subsection{Water}

Locally available potable drinking water was used in the experimental work for all mixes.

\subsection{Bacteria}

In this research, Bacillus subtilis bacteria were used, cultured at DVS Bio life Pvt Ltd Laboratory, Hyderabad, India.

\subsection{Calcium lactate}

Calcium lactate was used for the investigation, together with Bacillus subtilis bacteria as the nutrient broth. It was available in powder form with a white color.

\subsection{Culturing of Bacillus Subtilis}

Primary preparation of the nutrient broth (medium) was made by adding 2.5 grams of peptone, 1.5 grams of beef extract and 2.5 grams of sodium chloride $(\mathrm{NaCl})$ to $500 \mathrm{ml}$ of distilled water in a conical flask, which was enclosed with a cotton stopper and silver foil.
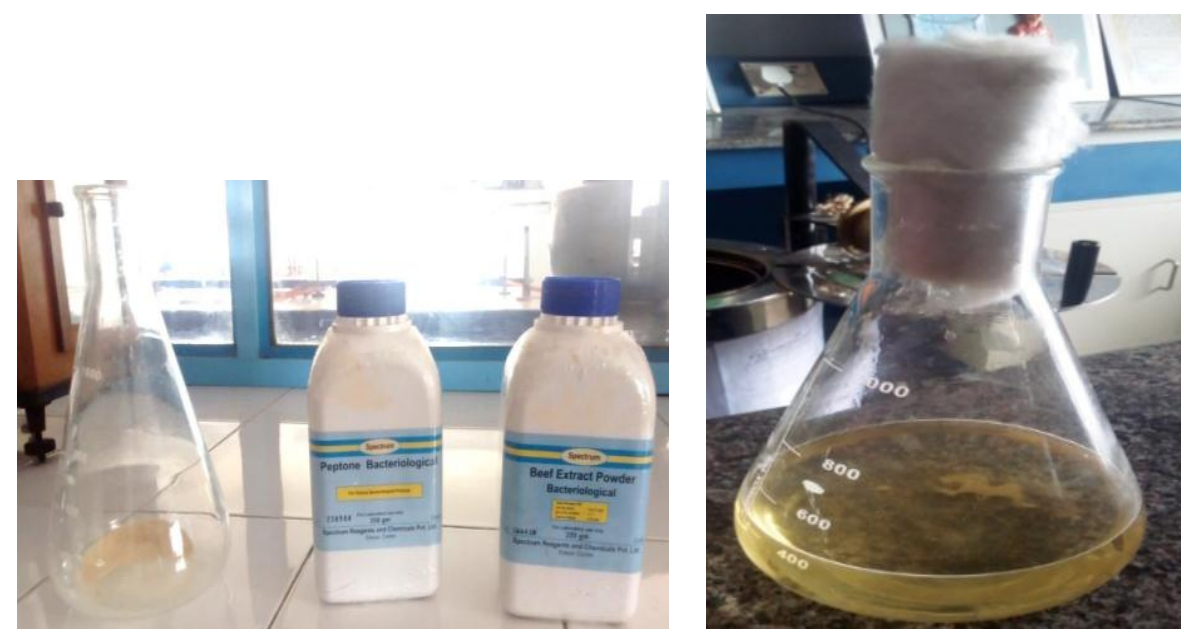

Figure 3 Making the nutrient broth solution 
The solution was untainted using an autoclave for around 20 minutes at a constant temperature of $121^{\circ} \mathrm{C}$ and pressure of $15 \mathrm{lbs}$. After sterilization, the solution was impurity-free with a clear orange shade.

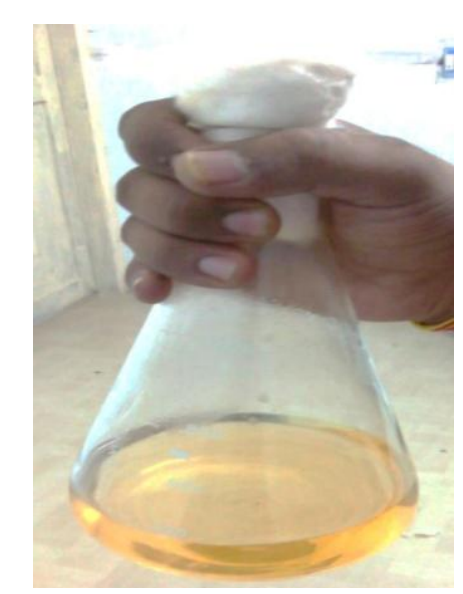

Figure 4 Contaminant-free solution after the sterilization process

Subsequently, the flask was opened in a lamina air flow chamber and a small pinch of the bacteria was added to the solution, as shown in Figure 5.
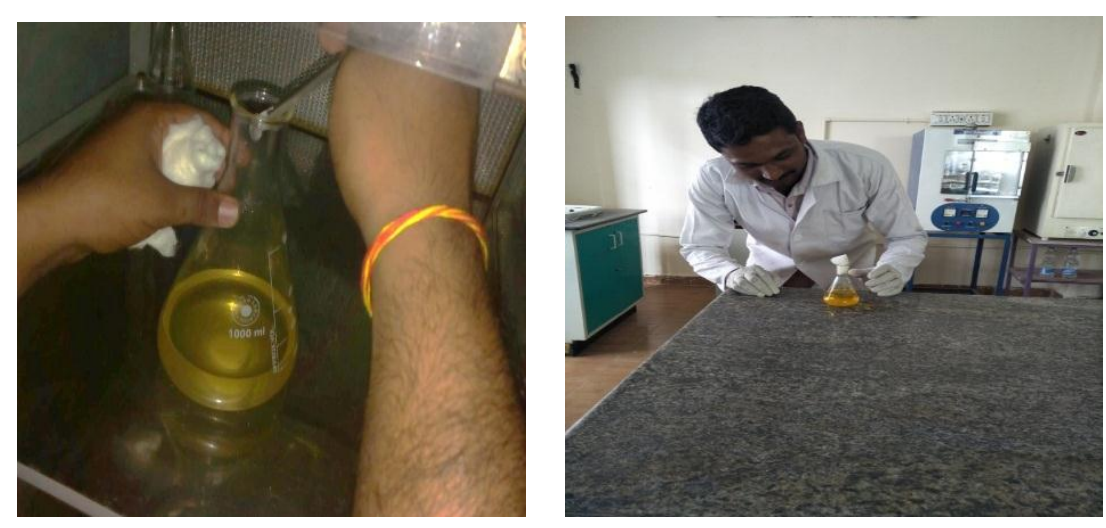

Figure 5 Adding the Bacillus subtilis to the nutrient broth medium in an aseptic room with laminar air flow equipment

It was then incubated in an orbital shaker at a speed of $125 \mathrm{rpm}$ and temperature of $37^{\circ} \mathrm{C}$. After 24 hours, it was observed that the shade of the bacterial arrangement had changed to a turbid whitish yellow, as can be seen in the figure which also shows the development of the Bacillus subtilis.

\subsection{Mix Design}

The mix proportions for the M40 grade concrete were designed using IS: 10262-2009. The materials required per $1 \mathrm{~m}^{3}$ of concrete are shown in Table 2.

\subsection{Compression Test}

A compression test on bacterial concrete specimens with dimensions of $150 \times 150 \times 150 \mathrm{~mm}$ was conducted as per IS: 516-1959 specifications. The specimens were prepared and cured for 28, 90 and 365 days, as per IS:456-2000 standards.

\subsection{Flexural Test}

A flexural test on bacterial concrete prism specimens with dimensions of $500 \times 100 \times 100 \mathrm{~mm}$ was also conducted, as per IS:516-1959. 
Table 2 Concrete mix proportions

\begin{tabular}{|c|c|c|c|c|c|c|c|c|}
\hline Mixture & $\mathrm{RBC} 00$ & $\mathrm{RBC} 05$ & $\mathrm{RBC} 10$ & RBC15 & $\mathrm{CBC} 00$ & $\mathrm{CBC} 05$ & CBC10 & CBC15 \\
\hline Cement $\left(\mathrm{kg} / \mathrm{m}^{3}\right)$ & 390 & 390 & 390 & 390 & 390 & 390 & 390 & 390 \\
\hline River sand $\left(\mathrm{kg} / \mathrm{m}^{3}\right)$ & 642 & 642 & 642 & 642 & -- & -- & -- & -- \\
\hline $\begin{array}{l}\text { Crushed rock sand } \\
\left(\mathrm{kg} / \mathrm{m}^{3}\right)\end{array}$ & -- & -- & -- & -- & 642 & 642 & 642 & 642 \\
\hline $\begin{array}{l}\text { Coarse aggregate } \\
\left(\mathrm{kg} / \mathrm{m}^{3}\right)\end{array}$ & 1261 & 1261 & 1261 & 1261 & 1261 & 1261 & 1261 & 1261 \\
\hline w/c ratio & 0.42 & 0.42 & 0.42 & 0.42 & 0.42 & 0.42 & 0.42 & 0.42 \\
\hline Bacterial cells (cfu/ml) & $10^{5}$ & $10^{5}$ & $10^{5}$ & $10^{5}$ & $10^{5}$ & $10^{5}$ & $10^{5}$ & $10^{5}$ \\
\hline $\begin{array}{l}\text { Percentage of bacterial } \\
\text { solution }\end{array}$ & 00 & 05 & 10 & 15 & 00 & 05 & 10 & 15 \\
\hline
\end{tabular}

RBC: Bacterial concrete with river sand; $\mathrm{CBC}$ : Bacterial concrete with crushed rock sand

\subsection{Cantabro Loss Test}

This test was performed with a Los Angeles abrasion testing instrument by the exclusive of abrasive charges in the form of steel balls, in accordance with ASTM C1747. The three cylindrical specimens of $150 \mathrm{~mm}$ diameter and $100 \mathrm{~mm}$ height were placed in the machine, as shown in Figures 6 and 7.

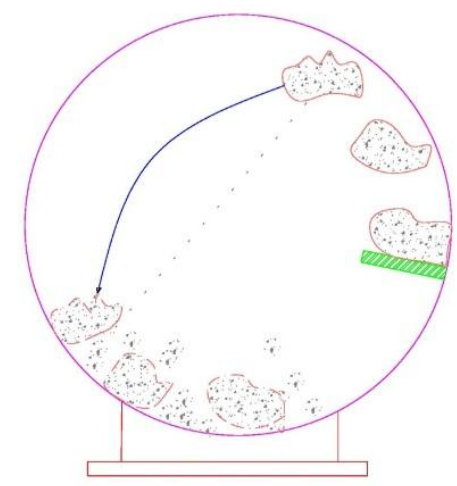

Figure 6 Illustration of Cantabro loss test

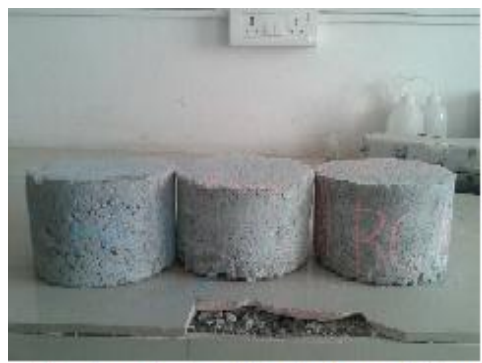

Specimen before Placing into Mchine

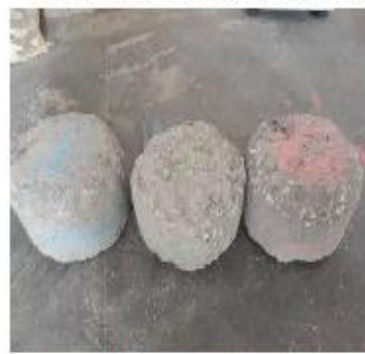

After 150 Revolutions

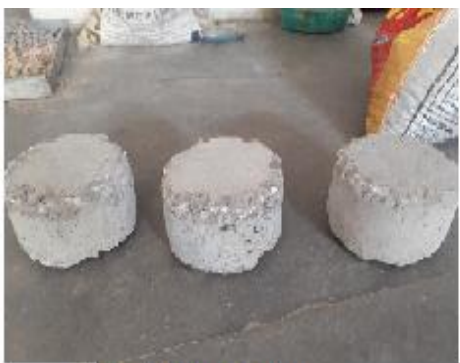

After 50 Revolutions

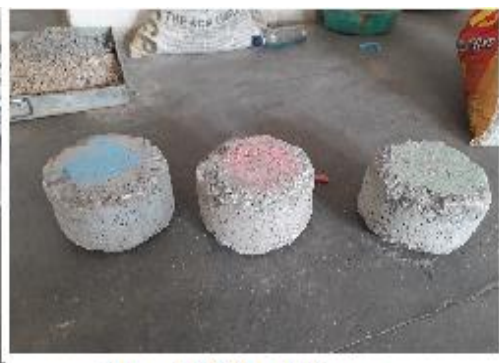

After 100 Revolutions

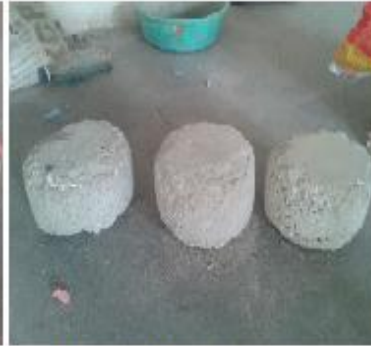

After 200 Revolutions

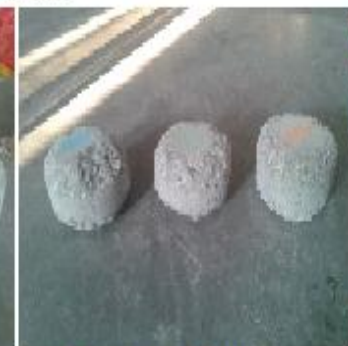

After 250 Revolutions

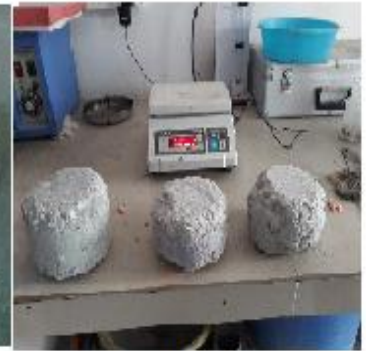

After 300 Revolutions 
Figure 7 Shape of specimens in the Cantabro loss test

The initial weight of each specimen $\left(\mathrm{M}_{1}\right)$ was noted before placing it into the machine. The machine was then allowed to rotate at various revolution levels, such as 50, 100, 150, 200, 250 and 300 revolutions. At each revolution level, the abraded specimens were cleaned for any loose debris and weighed accurately to measure the $\mathrm{M}_{2}$. Finally, the percentage loss was calculated using the following equation:

$$
\begin{aligned}
& \text { Cantabro Loss, } \%=\frac{M 1-M 2}{M 1} \\
& \times 100
\end{aligned}
$$

where $\mathrm{M}_{1}$ is the initial weight of the test specimen, and $\mathrm{M}_{2}$ is the final weight of the test specimen.

\section{RESULTS AND DISCUSSION}

\subsection{Effect of the Bacterial Solution on the Compressive Strength of Bacterial Concrete} The effect of the bacterial solution on compressive strength is shown in Figure 8. The percentage increases in compressive strength for BC-5\%, BC-10\% and $\mathrm{BC}-15 \%$ were $8.98 \%, 17.02 \%$ and $4.65 \%$, respectively at 28 days, which is very good when compared to the control mix concrete.

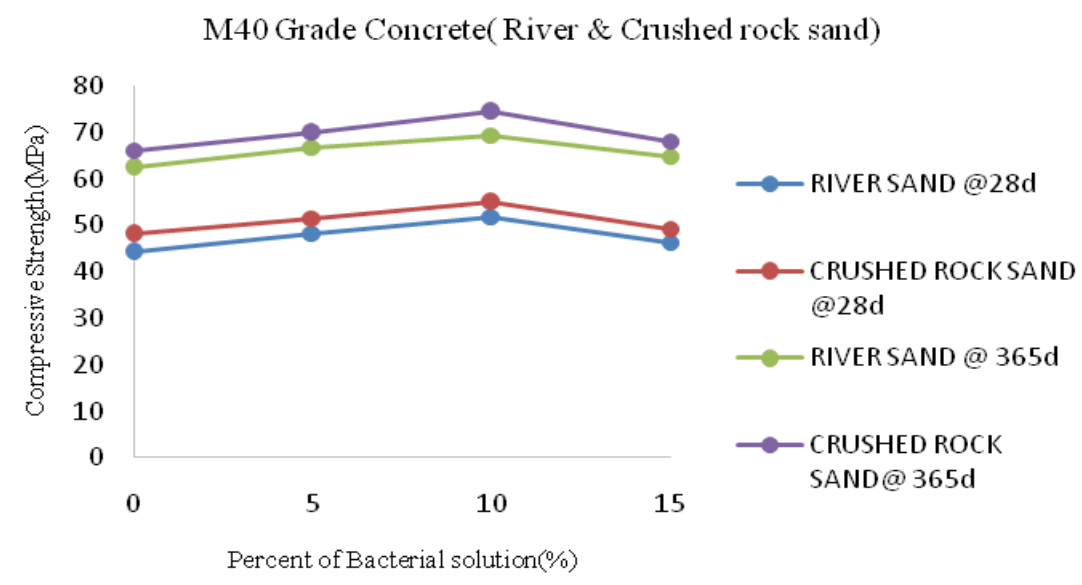

Figure 8 Effect of the bacterial solution on the compressive strength of bacterial concrete

At 180 days the increases were $6.86 \%, 12.54 \%$ and $4.63 \%$, respectively, while at 365 days these percentages were $6.88 \%, 11.22 \%$ and $3.84 \%$, respectively for $\mathrm{BC}-5 \%$, BC-10\% and BC-15\%. The percentage increases in the compressive strength of the crushed rock sand mixes at 28 days for $\mathrm{BC}-5 \%, \mathrm{BC}-10 \%$ and $\mathrm{BC}-15 \%$ were $6.94 \%, 14 \%$ and $2.28 \%$, respectively, while at 180 days they were $8.72 \%, 14.81 \%$ and $5.31 \%$, respectively. At 365 days these percentages were $5.65 \%$, $12.68 \%$ and $3.11 \%$, respectively for BC-5\%, BC-10\% and BC-15\%. From these figures it can be noticed that the gain in compressive strength at 180 days and 365 days is higher than that 28 days because the contribution of Bacillus subtilis bacteria together with calcium lactate to compressive strength is prominent at ages of more than 28 days for both river and crushed sand mixes. With the increase in the percentage of bacteria in the concrete ranging between $0 \%$ and $10 \%$ compressive strength also increased, but at $15 \%$ it decreased; this was because of the way that hydration products are saturated at $10 \%$ bacterial solution, so further increases in the solution do not contribute to strength, in fact reducing it. The crushed rock sand mixes showed more promising results than the river sand mixes due to the cubical sharp-edged faces of the grains in the rock. 


\subsection{Effect of the bacterial solution on the flexural strength of bacterial concrete}

The effect of the bacterial solution on flexural strength is shown in Figure 9. The percentage increases in the flexural strength of the river sand mixes for BC-5\%, BC-10\% and BC-15\% were $4.97 \%, 9.04 \%$ and $2.26 \%$ respectively at 28 days, while those at 180 days were $1.95 \%, 7.81 \%$ and $1.17 \%$, respectively.

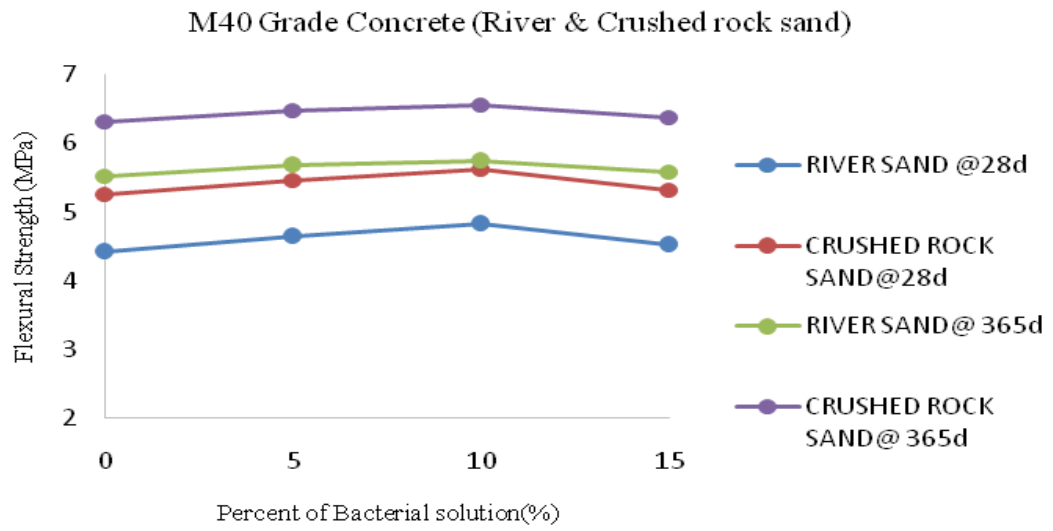

Figure 9 Effect of the bacterial solution on the flexural strength of bacterial concrete

At 365 days these percentages were $2.89 \%, 3.98 \%$ and $1.08 \%$, respectively for $\mathrm{BC}-5 \%$, BC-10\% and $\mathrm{BC}-15 \%$. In the crushed rock sand mixes, the percentage increases in flexural strength at 28 days for $\mathrm{BC}-5 \%, \mathrm{BC}-10 \%$ and $\mathrm{BC}-15 \%$ were $3.8 \%, 6.84 \%$ and $1.14 \%$, respectively, while at 180 days they were $1.99 \%, 5.64 \%$ and $0.66 \%$, respectively. At 365 days these percentages were $2.53 \%, 3.79 \%$ and $0.94 \%$, respectively for $\mathrm{BC}-5 \%, \mathrm{BC}-10 \%$ and $\mathrm{BC}-15 \%$. In addition, the percentage of bacterial concrete increased from $0 \%$ to $10 \%$ and the flexural strength also increased, but at $15 \%$ it decreased, for the same reason detailed in the previous section.

\subsection{Effect of Crushed Rock Sand on Cantabro Loss of Bacterial Concrete}

From the above test results, the Cantabro loss for the crushed rock mixes was good compared to the river sand mixes. The loss was highest at $10 \%$ bacterial solution in both the river sand and crushed rock mixes.

Table 3 Average Cantabro loss of bacterial concrete with river sand

\begin{tabular}{ccccc}
\hline $\begin{array}{c}\text { Percentage of } \\
\text { bacteria in concrete }\end{array}$ & $\begin{array}{c}\text { Cantabro loss } \\
\text { @3 days (\%) }\end{array}$ & $\begin{array}{c}\text { Cantabro loss } \\
\text { @ 7days (\%) }\end{array}$ & $\begin{array}{c}\text { Cantabro loss } \\
\text { @ 14 days (\%) }\end{array}$ & $\begin{array}{c}\text { Cantabro loss } \\
\text { @ 28 days (\%) }\end{array}$ \\
\hline 0 & 13.24 & 12.87 & 12.11 & 11.36 \\
5 & 14.92 & 12.22 & 11.56 & 9.86 \\
10 & 10.11 & 9.23 & 8.15 & 7.45 \\
15 & 15.23 & 14.88 & 12.35 & 11.58 \\
\hline
\end{tabular}

Table 4 Average Cantabro loss of bacterial concrete with crushed sand

\begin{tabular}{ccccc}
\hline $\begin{array}{c}\text { Percentage of } \\
\text { bacteria in concrete }\end{array}$ & $\begin{array}{c}\text { Cantabro loss } \\
\text { @3 days (\%) }\end{array}$ & $\begin{array}{c}\text { Cantabro loss } \\
\text { @ 7days (\%) }\end{array}$ & $\begin{array}{c}\text { Cantabro loss } \\
\text { @ 14 days (\%) }\end{array}$ & $\begin{array}{c}\text { Cantabro loss } \\
\text { @28 days (\%) }\end{array}$ \\
\hline 0 & 12.46 & 11.62 & 11.06 & 10.34 \\
5 & 11.24 & 9.48 & 10.46 & 8.82 \\
10 & 8.64 & 7.84 & 7.12 & 7.06 \\
15 & 14.34 & 13.86 & 13.98 & 12.44 \\
\hline
\end{tabular}


Figure 7 shows the specimens before and after Cantabro loss. In the machine the specimens collided with each other and also with the machine edges. This was used for measuring wear and tear action in pavements.

\subsection{Scanning Electron Microscopy (SEM) Analysis}

The SEM analysis images for control with a magnification of 10000 and 2500, sub acceleration voltage of 10000 volts, and pixel sizes of 9.921875 and 39.6875. Figure 9 shows the micro structure of the conventional concrete. The SEM analysis images for bacterial concrete with a magnification of 10000, 20000 and 2500, sub acceleration voltage 10000 volts, and pixel sizes of 9.921875, 4.960938 and 39.6875. Figure 10 shows the micro structure of the bacterial concrete, while the SEM analysis image shows the occurrence of calcite precipitation in the concrete. CSH, $\mathrm{CH}$ and pores were present in every sample and calcite was observed in the pores in the case of bacterial concrete (Santhosh et al., 2000). This clearly shows that the porosity decreased and gained in strength and that the cracks also healed due to calcite formation.
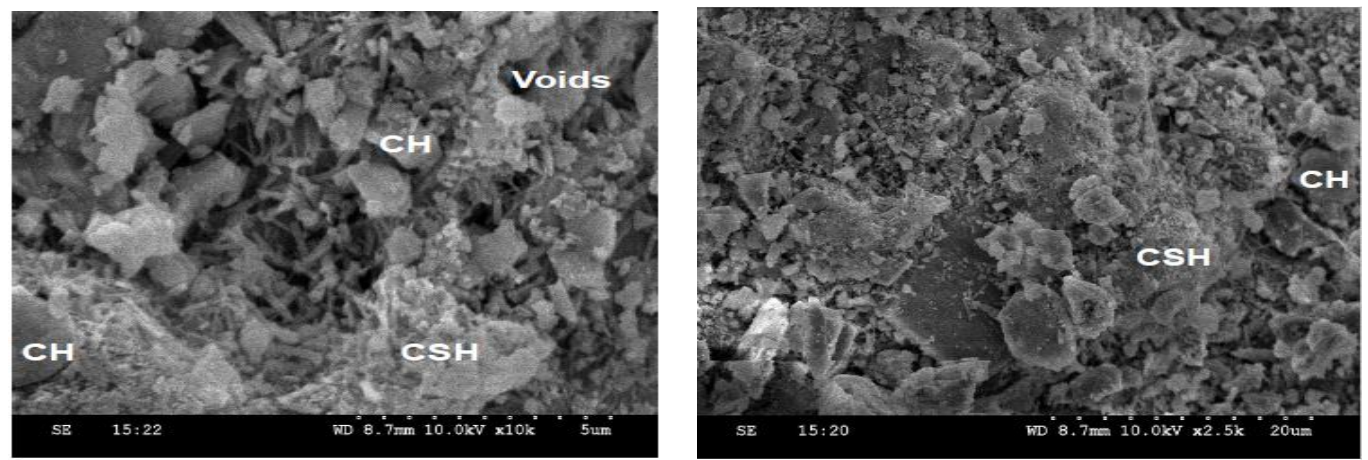

Figure 9 SEM micrograph of the control concrete
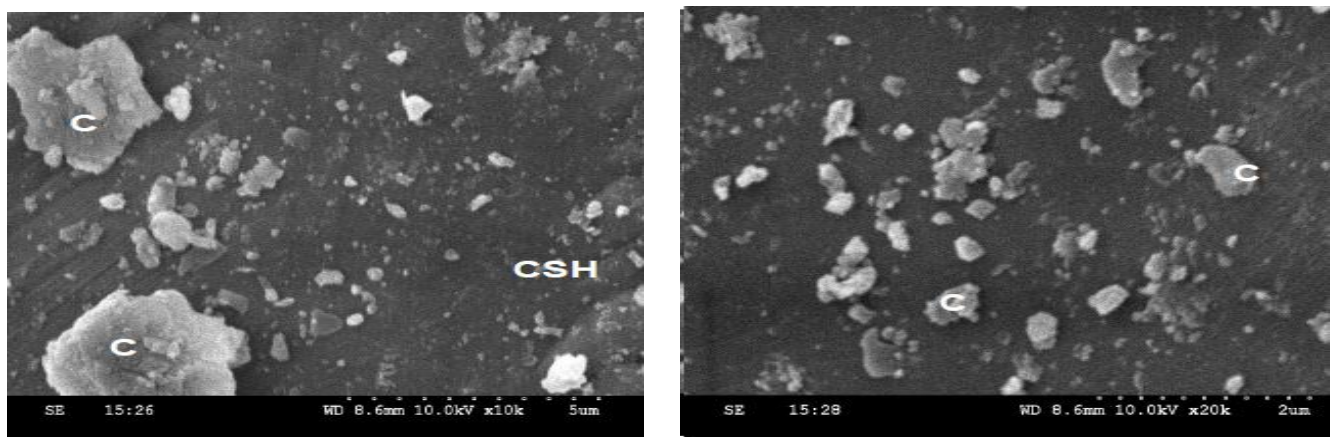

Figure 10 SEM micrograph of the bacterial concrete

\subsection{Proposed Empirical Relation between the Compressive and Flexural Strength of Bacterial Concrete}

Figures 11 and 12 show the relationship between the compressive and flexural strength of the bacterial concrete at different bacterial percentages (BC-5\%, BC-10\% and BC-15\%) (Anbuvelan.et.al, 2014). From the experimental results, the empirical relation for the bacterial solution is proposed as follows:

$$
\begin{aligned}
& f_{t}=0.66 \sqrt{f_{c k}} \\
& f_{t}=0.89 f_{c k}^{0.46}
\end{aligned}
$$


M40 Grade Concrete (River sand)

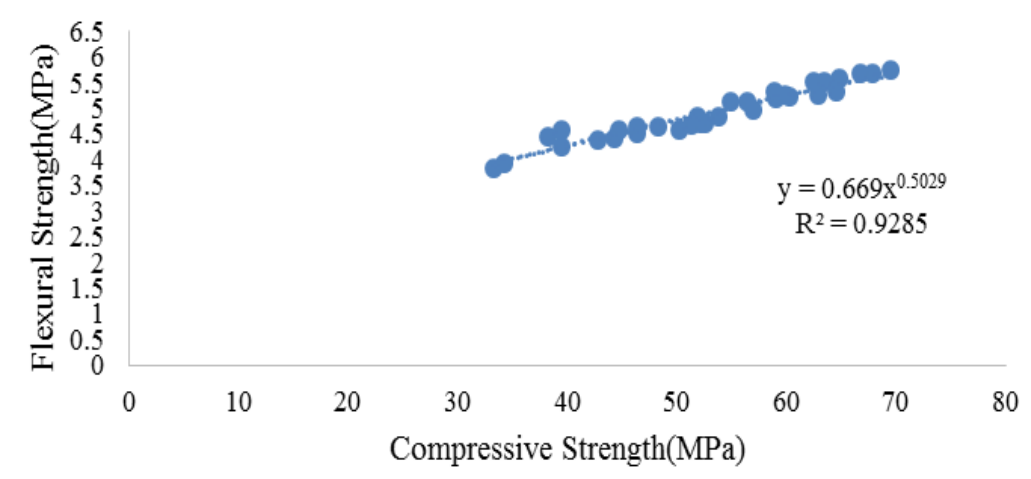

Figure 11 Empirical relation between compressive and flexural strength (river sand)

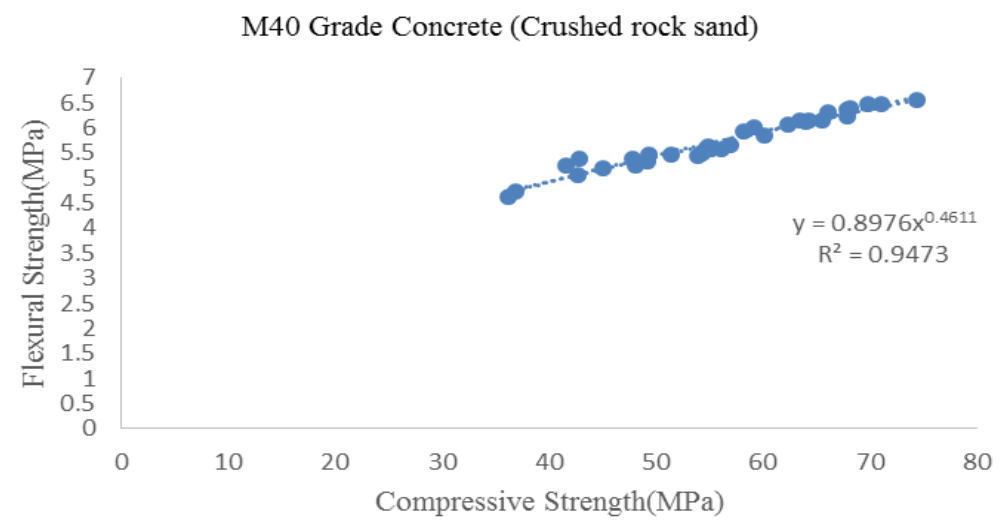

Figure 12 Empirical relation between compressive and flexural strength (crushed rock sand)

\section{CONCLUSION}

From the experimental work conducted on the bacterial concrete mixes, the following conclusions can be drawn: (1) The Cantabro loss, i.e. the abrasion resistance of bacterial concrete mixes, is strongly influenced the flexural strength; (2) the Cantabro loss is good at $10 \%$ bacteria in the crushed sand bacterial concrete mixes; (3) the flexural strength values increased and Cantabro loss decreased at up to $10 \%$ bacterial solution in the bacterial concrete mixes; (4) the addition of bacteria to concrete significantly improved the Cantabro loss and flexural strength at all ages; (5) the strength of the bacterial concrete for crushed rock sand mixes showed higher values than river sand mixes at all ages, irrespective of the percentage bacterial solution; (6) based on the test results, the optimum dosage of bacterial solution to improve strength at any age is $10 \%$ by weight of cement; an empirical relation exists between the compressive and flexural strength of bacterial concrete, which can be presented in the form $f_{t}=0.66 \sqrt{f_{c k}}$ for river mixes and $f_{t}=0.89 f_{c k}^{0.46}$ for crushed rock sand; and (7) the SEM analysis showed that the presence of calcium carbonate in bacterial concrete.

\section{REFERENCES}

Anbuvelan, K., Subramanian, K., 2014. An Empirical Relationship between Modulus of Elasticity, Modulus of Rupture and Compressive Strength of M60 Concrete Containing Metakaolin. Research Journal of Applied Sciences, Engineering and Technology, Volume 8(11), pp. 1294-1298 
ASTM C1747/C1747M. 2011. Standard Test Method for Determining Potential Resistance to Degradation of Pervious Concrete by Impact and Abrasion. American Society of Testing and Materials International

IS: 4031-1980. Methods of Physical Test for Hydraulic Cement-Determination of Consistency of Standard Cement Paste. Bureau of Indian Standard, New Delhi

IS:10262-2009. Concrete Mix Proportioning Guidelines (first revision). Bureau of Indian Standard, New Delhi

IS: 456-2000. Plain and Reinforced Concrete - Code of Practice. Bureau of Indian Standard, New Delhi

IS: 516-1959. Methods of Tests for Strength of Concrete. Bureau of Indian Standard, New Delhi IS: 12269-1987, Indian Standard 53 Grade OPC

Jonkers, H.M., Thijssen, A., Muyzer, G., Copuroglu, O., Schlangen, E., 2010. Application of Bacteria as Self-healing Agent for the Development of Sustainable Concrete. Ecological Engineering, Volume 36(2), pp. 230-235

Jonkers, H.M., Schlangen, E., 2007. Crack Repair by Concrete-immobilized Bacteria. In: Proceedings of the First International Conference on Self-Healing Materials, pp. 18-20

Jonkers, H.M., 2011. Bacteria-based Self-healing Concrete. Heron, Volume 56(1/2), pp. 1-12

Joseph, C., Jefferson, A.D., Cantoni, M.B., 2007. Issues Relating to the Autonomic Healing of Cementitious Materials. In: First International Conference on Self-healing Materials. pp. 18

Kessler, M.R., Sottos, N.R., White, S.R., 2003. Self-healing Structural Composite Materials. Composites Part A: Applied Science and Manufacturing, Volume 34(8), pp. 743-753

Kumar, A.A., Raguraam, S., 2018. Comparison of Fresh and Hardened Properties of Normal, Self-Compacting and Smart Dynamic Concrete. International Journal of Technology, Volume 9(4), pp. 707-714

Li, V.C., Herbert, E., 2012. Robust Self-healing Concrete for Sustainable Infrastructure. Journal of Advanced Concrete Technology, Volume 10(6), pp. 207-218

Dong, Q., Wu, H., Huang, B., Shu, X., Wang, K., 2010. Development of a Simple and Fast Test Method for Measuring the Durability of Portland Cement Pervious Concrete. Report PCA R\&D Serial No. SN3149, Portland Cement Association, 5420 Old Orchard Road Skokie, Illinois, USA

Ramadhansyah, P.J., Bakar, B.H.A., Azmi, M.J.M., Ibrahim, M.H.W., 2011. Engineering Properties of Normal Concrete Grade 40 Containing Rice Husk Ash at Different Grinding Times. International Journal of Technology, Volume 2(1), pp. 10-19

Ramakrishnan, V., Ramesh, K.P., Bang, S.S., 2001. Bacterial Concrete. In: Proceeding Smart Materials, International Society for Optics and Photonics, Volume 4234, pp. 168-177

Rao, S.K., Sravana, P., Rao, T.C., 2016. Investigating the Effect of M-sand on Abrasion Resistance of Fly Ash Roller Compacted Concrete (FRCC). Construction and Building Materials, Volume 118, pp. 352-363

Reddy, S., Satya, A., Rao, S., Azmatunnisa, M., 2012. A Biological Approach to Enhance Strength and Durability in Concrete Structures. International Journal of Advances in Engineering \& Technology, Volume 4(2), pp. 392-399

Santhosh, K.R., Ramakrishnan, V., Duke, E.F., Bang, S.S. 2000. SEM Investigation of Microbial Calcite Precipitation in Cement. In: Proceedings of the International Conference on Cement Microscopy. International Cement Microscopy Association, Volume 22, pp. 293-305

Schlangen, E., Jonkers, H.M., Qian, S., Garcia, A. 2010. Recent Advances on Self-healing of Concrete. In: FraMCos-7: Proceedings of the $7^{\text {th }}$ International Conference on Fracture Mechanics of Concrete and Concrete Structures, Jeju Island, Korea, pp. 23-28 
Wang. J., Van Tittelboom, K., De Belie, N., Verstraete, W., 2012. Use of Silica Gel or Polyurethane Immobilized Bacteria for Self-healing Concrete. Construction and Building Materials, Volume 26(1), pp. 532-540

Zwaag, S., 2008. Self-healing Materials: An Alternative Approach to 20 Centuries of Materials Science. Springer Science+ Business Media BV, Volume 30(6), pp. 20-21 